\title{
CHEMICAL ANALYSIS AND CYTOTOXIC ACTIVITY OF N- HEXANE FRACTION OF Zanthoxylum acanthopodium DC. FRUITS
}

\author{
Denny Satria ${ }^{1,5}$, Jansen Silalahi ${ }^{2}$, Ginda Haro ${ }^{2}$, Syafruddin Ilyas ${ }^{3}$ \\ and Poppy Anjelisa Zaitun Hasibuan ${ }^{4 *}$ \\ ${ }^{1}$ Department of Pharmaceutical Biology, ${ }^{2}$ Department of Pharmaceutical Chemistry, \\ ${ }^{3}$ Department of Biology, ${ }^{4}$ Department of Pharmacology \\ ${ }^{1,2,4}$ Faculty of Pharmacy, ${ }^{3}$ Faculty of Mathematics and Natural Sciences, \\ Universitas Sumatera Utara, Medan, Indonesia, 20155. \\ ${ }^{5}$ Faculty of Pharmacy and Health Sciences, Universitas Sari Mutiara Indonesia, Medan, \\ Indonesia, 20123. \\ *E-mail: poppyanjelisa@usu.ac.id
}

\begin{abstract}
Zanthoxylum acanthopodium DC. the fruit is a potential anticancer agent. This study was evaluated the anticancer activity of n-hexane fraction (nHF) of Zanthoxylum acanthopodium DC. fruit towards T47D cell line. nHFwere analyzed for chemical constituents and tested for cytotoxicity, cell cycle inhibition, apoptosis induction and inhibition of cyclin D1 expression. nHF was found to contain monoterpenes and sesquiterpenes with geranyl acetate (26.34\%) as major compound. nHF of Zanthoxylum acanthopodium DC. Fruits were found to have $\mathrm{IC}_{50} 85.41 \pm 0.78 \mu \mathrm{g} / \mathrm{mL}$, cause accumulation in $\mathrm{G}_{0}-\mathrm{G}_{1}$ phase, increased apoptosis and decreased cyclin $\mathrm{D} 1$ expression. The results reveal that nHF of Zanthoxylum acanthopodium DC. fruits have cytotoxic activities by inhibition cell cycle and induction apoptosis. Our further study is to isolate compounds that responsible for the cytotoxic activity.
\end{abstract}

Keywords: Cytotoxic, chemical constituents, Zanthoxylum acanthopodium DC., n-hexane fraction.

(c) RASĀYAN. All rights reserved

\section{INTRODUCTION}

Breast cancer has been known as the leading of cancer in women after cervical cancer. Alteration in lifestyle and diet are the main factor affecting the number of breast cancer patients. The high incidence and the high cost dealing with this cancer which patients should pay for their life, hence there is an urgent need for developing an alternative source of medicine especially from traditional medicine to treat breast cancer patients ${ }^{1-3}$.

Zanthoxylum acanthopodium DC. has been used as a tonic and medicate dysentery. Andaliman has been used as a seasoning at North Sumatera ${ }^{4-6}$. Zanthoxylum genus has many active compounds such as steroids/triterpenoids, hydroquinones, flavonoids, tannins, glycosides, volatile oils, alkaloids, coumarins, lignans, amides, and terpenes ${ }^{7-14}$. Ethyl acetate fraction was reported active towards breast cancer cell lines and found to have a synergistic effect with doxorubicin. It was showed to have anticancer activity on in vivo study, cardioprotective effect and active on breast cancer resistance cells ${ }^{15-17}$. The purpose of this study was to analysis phytochemical components and determine cytotoxicity activity of n-hexane fraction of Zanthoxylum acanthopodium DC. fruits.

\section{EXPERIMENTAL}

\section{Plant and Chemical Materials}

Fresh fruits were collected from Onan Rungu village, Toba Samosir Regency, Sumatera Utara province, Indonesia. Chemicals used were annexin-V (BioLegend), distilled water, [3-(4,5-dimethylthiazole-2-yl)2,5-diphenyl tetrazolium bromide] (Sigma), PI kit (BioLegend), FITC cyclin D1 antibody (Santa Cruz).

Rasayan J. Chem., 12(2), 803-808(2019)

http://dx.doi.org/10.31788/RJC.2019.1225180 


\section{Preparation of n-Hexane Fraction (nHF)}

The simplex powder of Zanthoxylum acanthopodium DC.(1000 g) was fractionated with n-hexane by maceration based on previous study ${ }^{17-19}$.

\section{Analysis of Chemical Constituents by Gas Chromatography}

nHF was analyzed with GC-MS Thermo Scientific Trace 1310 (Thermo) gas chromatograph with a fused silica capillary column (TG-5MS, $30 \mathrm{~m} \times 0.25 \mathrm{~mm}$, film $0.25 \mu \mathrm{m}$ ) using helium as a carrier gas with a flow rate of $1.02 \mathrm{~mL} /$ minute and with temperature programming from $70^{\circ} \mathrm{C}$ for 5 minutes to $280^{\circ} \mathrm{C}$ with increase temperature $5^{\circ} \mathrm{C} /$ minute. The injector temperature was set at $280^{\circ} \mathrm{C}$. The Mass Spectrometer was performed using an interface temperature of $280^{\circ} \mathrm{C}$ and an electron impact ionization of $70 \mathrm{eV}$ with a scan mass range of $40-500 \mathrm{~m} / \mathrm{z}$ (sampling rate $1.0 \mathrm{scan} / \mathrm{s})^{20-21}$.

\section{Cytotoxicity Assay}

The cells were treated with nHF. In this test, T47D cell line was grown in RPMI 1640 medium based on the previous study by Hasibuan, et al (2015) and Harahap, et al (2018)

\section{Preparation of Cells for Flow Cytometry Analysis}

T47D cells $\left(7.5 \times 10^{5}\right.$ cells/well) were seeded into a 6-well plate and incubated for $24 \mathrm{~h}$. After that, the cells were treated with $\mathrm{nHF}$ and then incubated for $24 \mathrm{~h}$. Cells were collected and washed, centrifuged at 2500 rpm for 5 min and the sediment was collected ${ }^{17-18}$.

\section{Cell Cycle Analysis}

Cells were fixed in cold $70 \%$ ethanol in PBS at $-20^{\circ} \mathrm{C}$ for $2 \mathrm{~h}$. PI kit (BioLegend) added to sediment and resuspended and incubated at $37^{\circ} \mathrm{C}$ for $30 \mathrm{~min}$. The samples were analyzed using FACScan flow cytometer. Percentage of cells in each of stage in the cell cycle were calculated using ModFit Lt. 3.0. $\mathrm{s}^{22}$.

\section{Apoptosis Analysis}

Annexin V kit was added to sediment and suspended and incubated at $37^{\circ} \mathrm{C}$ for $30 \mathrm{~min}$. The samples were analyzed using FACScanflowcytometer ${ }^{23}$.

\section{Cyclin D1 Expression}

Sediment cells were fixated with ethanol $70 \%$ and allowed to stand for $2 \mathrm{~h}$ in $-20^{\circ} \mathrm{C}$ and Cyclin D1 antibody was added and incubated at $37^{\circ} \mathrm{C}$ for $10 \mathrm{~min}$. The samples were analyzed using FACScanflowcytometer ${ }^{24}$.

\section{Statistical Analysis}

Data were expressed as mean $\pm \mathrm{SD}$.

\section{Chemical Constituents of n-Hexane Fraction}

\section{RESULTS AND DISCUSSION}

Analysis of chemical compounds of n-hexane fraction with gas chromatography with mass spectrometry was resulted in 10 major compounds. Analysis of chemical compounds of nHF with GC-MS is shown in Fig.-1 and Table-1.

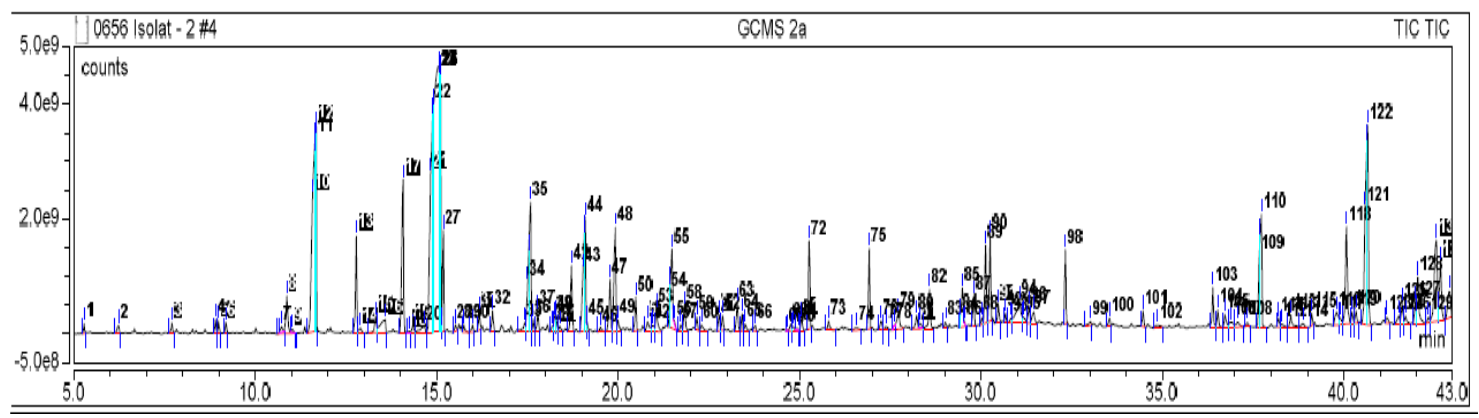

Fig.-1: GC-MS Chromatogram of nHF of Zanthoxylum acanthopodium DC. 
Inhibitory Concentration $50 \%\left(\mathrm{IC}_{50}\right)$

The $\mathrm{IC}_{50}$ score of $\mathrm{nHF}$ was $85.41 \pm 0.78 \mu \mathrm{g} / \mathrm{mL}$. The cytotoxicity activity is correlated to the constituent of bioactive compounds in plants including Zanthoxylum acanthopodium DC. Essential oils and triterpenoids/steroids estimated as active compounds ${ }^{25}$. Recent studies have reported that monoterpenes exert anticancer activities and as chemopreventive agents ${ }^{26-28}$ such as d-limonene, perillyl alcohol, and geraniol $^{29-34}$. Geraniol shows a broad spectrum of bioactivity as antimicrobial, antioxidant, antiulcer, antiinflammatory, neuroprotective and anti-breast cancer ${ }^{35-42}$.

Table-1: Percentage of Compounds in nHF of Zanthoxylum acanthopodium DC

\begin{tabular}{c|c|c}
\hline No. & Compound & Percentage (\%) \\
\hline 1 & Geranyl acetate & 26.34 \\
\hline 2 & Geraniol & 8.83 \\
\hline 3 & (E)-3,7-dimethylocta-2,6-diene-1-yl palmitate & 6.87 \\
\hline 4 & 2,6-dimethyl-3,5,7-octatriene-2-ol-E,E & 4.02 \\
\hline 5 & $(9 Z, 12 Z, 15 Z), 3-7-$ dimethyloct-6en-1-yl- \\
\hline 6 & Cartadecane-9,12,15- trienoat & 3.84 \\
\hline 7 & 3,7-dimethyloct-6-an-1-yl palmitate & 2.75 \\
\hline 8 & 17-octadecynoic acid & 2.07 \\
\hline 10 & Geranyl palmitoleate & 1.33 \\
\hline
\end{tabular}

\section{Cell Cycle Inhibition}

To evaluate the effect of nHF to increase cell death by modulating cell cycle was concentrated on it for further studies using the flow cytometry method. The effect of nHF is given in Fig.-2. Treatment with nHF in $42.5 \mu \mathrm{g} / \mathrm{mL}$ caused cell accumulation at $\mathrm{G}_{0}-\mathrm{G}_{1}$ phase $(49.94 \%)$ and for control cell $(45.37 \%)$. This fact was to indicate that $\mathrm{nHF}$ can inhibit cell growth at $\mathrm{G}_{0}-\mathrm{G}_{1}$ phase. In the cell cycle analysis, $\mathrm{nHF}$ exhibited higher $\mathrm{G}_{0}-\mathrm{G}_{1}$ phase accumulation compared to control cells. This analysis also showed that cells underwent apoptosis, indicated by the occurrence of apoptosis during inhibition of cell cycle on the $\mathrm{G}_{0}-\mathrm{G}_{1}$ phase. Evaluation of cell cycle inhibition was performed using flow cytometry method with propidium iodide as shown in Fig.-2.
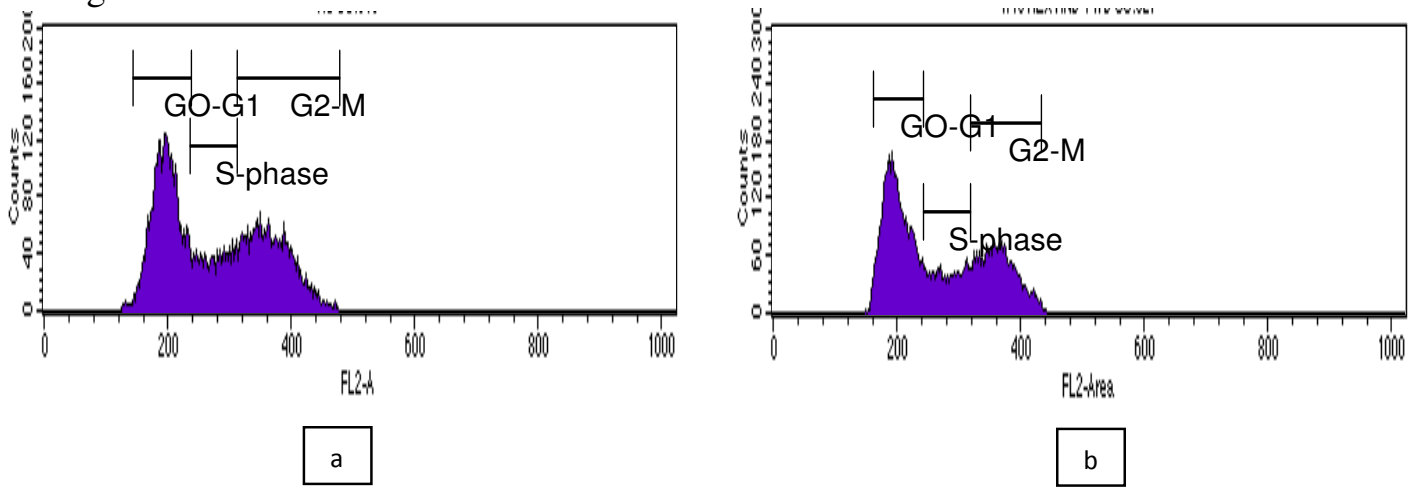

Fig.-2: T47D Cells were treated by nHF for 24h. (a) Control Cells; (b) nHF $42.5 \mu \mathrm{g} / \mathrm{mL}$. nHF exhibited $\mathrm{G}_{0}-\mathrm{G}_{1}$ Phase. 


\section{Apoptosis Induction}

Evaluation of apoptosis initiation was executed using a flow cytometry method with Annexin-V. As shown in Fig.-3, the cells in the upper and lower right quadrants represent late apoptotic/ necrotic and early apoptotic cells, respectively. The percentage of control and nHF in early apoptotic were $5.47 \%$ and $33.18 \%$, in late apoptotic/early necrotic are $1.76 \%$ and $7.25 \%$. In the apoptotic study, nHF increase the cells undergo apoptosis in early apoptosis and late apoptosis if compared to control T47D cell lines. Geraniol has been shown to be synergistic in combination with chemotherapy drugs.
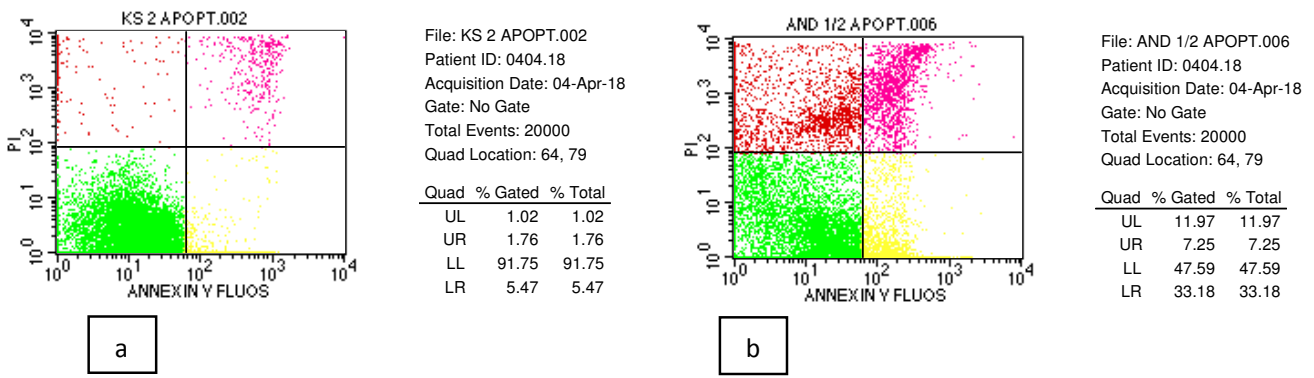

Fig.-3: T47D cells were treated with nHF for 24h (a) Control Cells; (b) nHF $42.5 \mu \mathrm{g} / \mathrm{mL}$.

Geraniol has been reported to manage various pathways and signaling and therefore the effect in the cell cycle, proliferation, apoptosis, autophagy and metabolism of cancer cells ${ }^{43-44}$. Geraniol suppresses the MCF-7 growth through induction cell cycle arrest ${ }^{41}$.

\section{Cyclin D1 Expression}

To evaluate the effect of nHF on cyclin D1 expression was conducted by flow cytometry method, and the results were given in Figure 4. Treatment with $\mathrm{nHF} 42.5 \mu \mathrm{g} / \mathrm{mL}$ caused cell accumulation in the M1 area $(22.24 \%)$ and for control cell $(11.19 \%)$. Evaluation of cyclin D1 expressions was performed using flow cytometry method with cyclin D1 antibody as shown in Fig.-4.
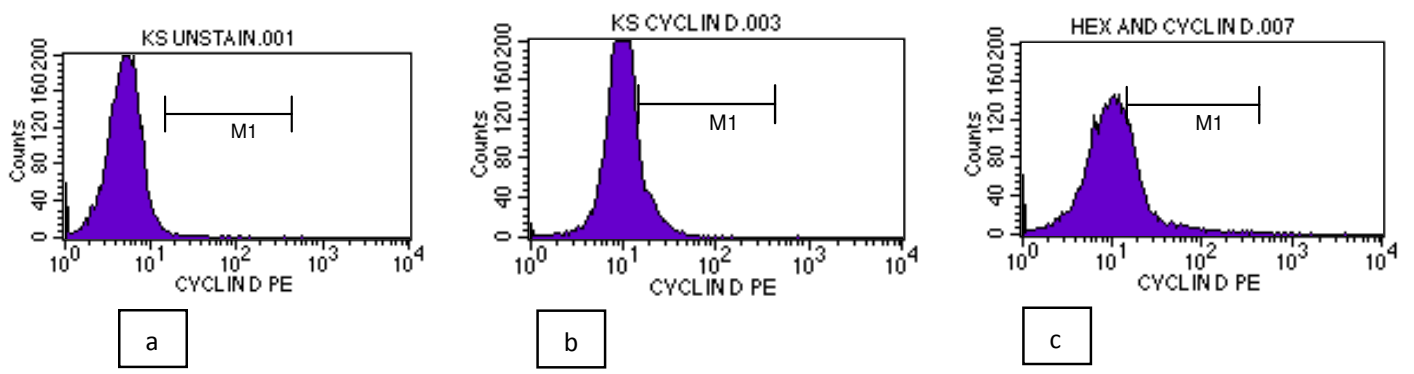

Figure 4. T47D cells were treated withnHF for 24h

(a) control cells unstaining; (b) control cells; (c) $\mathrm{nHF} 42.5 \mu \mathrm{g} / \mathrm{mL}$.

\section{CONCLUSION}

The results reveal that $\mathrm{n}$-hexane fraction of Zanthoxylum acanthopodium DC. fruits contain many bioactive compounds and effective as anticancer towards T47D cell lines by several mechanisms such as cell cycle inhibition, apoptosis induction and down-regulation of cyclin D1 expression.

\section{ACKNOWLEDGMENT}

We gratefully thank DP2M DIKTI (Directorate of Higher Education) Ministry of Research Technology and High Education, Indonesia through "Hibah Disertasi Doktor" and "Hibah Pascasarjana" Research Grant 2018 and 2016 for financial support in the study.

\section{REFERENCES}

1. A. Montazeri,M. Vahdaninia and I. Harirchi,Asia Pac Fam Med., 7, 6, (2008), DOI: 10.1186/1447056X-7-6

2. C.H. Yip, 2009 Breast cancer in Asia: Methods in molecular biology. Human Press, Totowa. 


\section{RASĀYAN J. Chem.}

Vol. 12 | No. 2 |803-808| April - June | 2019

3. P.F. Rezaei, S. Fouladdel, C. Silvia, S.M. Ghaffari, G.R. Amin and E. Azizi, Cytotechnology, 63, 503(2011), DOI: 10.1007/s10616-011-9373-6

4. E. Suryanto, H. Sastrohamidjojo, S. Raharjoand Tranggongo, Indonesian Food and Nutrition Progress,11(1), 15(2004), DOI: 10.22146/jifnp.26

5. S.R. Hynniewta and Y. Kumar, Indian Journal of Traditional Knowledge, 7(4), 581 (2008)

6. M. Sirait, M. Siahaanand Mangkudidjojo.1991, Thesis, Post Graduate School of Pharmacy, Institute Technology of Bandung, Indonesian.

7. A. Parhusip, 2006, Thesis, Post Graduate School of Bogor Agriculture Institute, Indonesian.

8. C.C. Fernandez, P.C. Vieira, V.C. daSilva, E.L. Dall'Oglio, L.E. daSilva and P.T. deSousa, J. Braz. Chem. Soc, 20(2), 379(2009), DOI: 10.1590/S0103-50532009000200025

9. P.A. Yao-Kuassi, C. Caron, H. Ramiarantosa, E. Prost, D. Harakat, E.L. Magrex-Debar, S.C. Gangloff, A.A. Coffy andM. Zeches-Hanrot, C.R Chimie,18, 891 (2015), DOI: 10.1016/j.crci.2015.01.005

10. J. Hu, X. Shi, X. Mao, J. Chen, H. Li, Chemistry \& Biodiversity, 11, 970(2014), DOI: $10.1002 / \mathrm{cbdv} .201300381$

11. J. Hu, W.D. Zhang, R.H. Liu, C. Zhang, Y.H. Shen, H.L. Li, M.J. Liang andX.K. Xu, Chemistry \& Biodiversity, 3, 990(2006), DOI: 10.1002/cbdv.200690108

12. Yang, Z.D., Zhang, D., Ren, J., Yang, M, Med Chem Res, 21, 722(2012), DOI: 10.1007/s00044-0119581-9

13. X.G.Cui, Q.J.Zhao, Q.L.Chen, L.Xu, Y.Song, Y.S.JinandD.F. Xu, Helvetica Chemica Acta, 91, 155 (2008), DOI: $10.1002 /$ hlca.200890006

14. J.J.Chen, C.K.Yang, Y.H.Kuo, T.L.Hwang, W.L.Kuo, Y.P.Lim, P.J.Sung, T.H.Chang, M.J.Cheng, Int. J. Mol. Sci, 16, 9719(2015), DOI: 10.3390/ijms16059719

15. P.A.Z.Hasibuan, U.Harahap, P.Sitorus, D.Satria, Der. Pharma. Chemica., 8(20), 172(2016)

16. Y.M.Sihotang, 2015, Thesis, Fakulty of Pharmacy,USU, Indonesian.

17. R.Anggraini, S.Hadisahputra, J.Silalahi, International Journal of PharmTech Research, 6(7),2032(2014).

18. D.Satria,J.Silalahi,G.Haro,S.Ilyas, P.A.Z.Hasibuan, Asian Pac. J. Cancer Prev., 18(2), 399(2017), DOI: $10.22034 / A P J P .2017 .18 .2 .399$

19. P.A.Z. Hasibuan,C.Jessy, D. Satria, Int. J. Pharm. Pharm. Sci.,7, 155(2015).

20. M. Moektiwardoyo, M.Muchtaridi and H.Eli, Int. J. Pharm. Pharm. Sci., 6(2), 547(2014).

21. M.Majumder, H.K.Sharma, K.Zaman and W.Lyngdoh, Int. J. Pharm. Pharm. Sci., 6(5), 543(2014)

22. U.Harahap, P.A.Z.Hasibuan, P.Sitorus, N.Arfian, D.Satria, Asian Pac. J. Cancer. Prev., 19(2), 565 (2018), DOI: 10.22034/APJCP.2018.19.2.565

23. A.Dalimunthe,P.A.Z.Hasibuan, D.Satria, Asian J. Pharm. Clin. Res.,10(11), 404(2017), DOI: 10.22159/ajpcr.2017.v10i11.20204

24. A.Żurynń,L.Anna, S.M.Barbara, K.W.Anna and Maciej G, Int. J. Onco.,48, 2521(2016), DOI: 10.3892/ijo.2016.3444

25. V.R.Yadav, P.Sahdeo, S.Bokyung, K.Ramaswamyand B.A.Bharat, Toxins, 2, 2428(2010), DOI: 10.3390/toxins 2102428

26. C.E.Elson and S.G.Yu, J. Nutr. 124, 607(1994), DOI: 10.1093/jn/124.5.607

27. G.J.Kelloff, C.W.Boone, J.A.Crowell, V.E.Steele, R.A.Lubet, L.A.Doody, W.F.Malone, E.T.Hawk and C.C.Sigman, J. Cell Biochem., 26, 1(1996), DOI: 10.1111/j.1749-6632.1999.tb08718.x

28. P.L.Crowell, J. Nutr.,129, 775S(1999), DOI: 10.1093/jn/129.3.775S

29. Y. Bhalla, V.K.Gupta and V. Jaitak, J. Sci. Food Agric., 93, 3643(2013), DOI: 10.1002/jsfa.6267

30. M. N.Gould, Environmental Health Perspective 105 (Suppl 4), 977(1997), DOI: 10.1289/ehp. 97105 s 4977

31. T.C.Chen, C.O.Fonseca and A.H.Schönthal, Am. J. Cancer Res., 5, 1580(2015)

32. D.Samaila, B.J.Toy, R.C.Wang and J.A.Elegbede, Anticancer Res., 24, 3089(2004), DOI: 10.1016/j.canlet.2007.07.020

33. S. Bardon, V.Foussard, S.Fournel and A.Loubat, Cancer Lett.,181, 187(2002), DOI: 10.1016/S03043835(02)00047-2 


\section{RASĀYAN J. Chem.}

Vol. 12 | No. 2 |803-808| April - June | 2019

34. M.V.Sobral, A.L.Xavier, T.C.Lima and D.P.de Sousa, Sci. World J., (2014), DOI: $10.1155 / 2014 / 953451$

35. F.Solórzano-Santos and M.G.Miranda-Novales, Curr. Opin. Biotechnol., 23, 136(2012), DOI: 10.1016/j.copbio.2011.08.005

36. M.Tiwari and P.Kakkar,Toxicol In Vitro, 23, 295(2009), DOI: 10.1016/j.tiv.2008.12.014

37. K.I.de Carvalho, F.Bonamin, R.C.Dos Santos, L.L.Périco, F.P.Beserra, D.P.de Sousa, J.M.Filho, L.R.da Rocha and C.A.Hiruma- Lima, Naunyn Schmiedebergs Arch Pharmacol, 387, 355(2014), DOI: 10.1007/s00210-013-0947-z

38. K.R.Rekha, G.P.Selvakumar, S.Sethupathy, K.Santha and R.I.Sivakamasundari, J. Mol. Neurosci.,51, 851(2013), DOI: 10.1007/s12031-013-0074-9.

39. Y. D. Burke, M. J. Stark, S. L. Roach, S. E. Sen and P. L. Crowell, Lipids, 32, 151(1997), DOI: 10.1007/s11745-997-0019-y

40. S.Carnesecchi, Y.Schneider, J.Ceraline, B.Duranton, F.Gosse, N.Seiler and F.Raul, J. Pharmacol. Exp. Ther., 298, 197(2001).

41. R. E. Duncan, D. Lau, A. El-Sohemy and M. C. Archer, Biochem Pharmacol, 68, 1739(2004), DOI: 10.1016/j.bcp.2004.06.022

42. T. P. Ong, R. Heidor, A. de Conti, M. L. Dagli and F. S. Moreno, Carcinogenesis, 27, 1194(2006), DOI: $10.1093 /$ carcin/bgi291

43. S. H. Kim, H. C.Bae, E.J.Park, C.R.Lee, B.J.Kim, S, H.H.Park, S.J.Kim, I.So, T.W.Kim, Biochem. Biophys. Res. Commun., 407, 129(2011), DOI: 10.1016/j.bbrc.2011.02.124

44. S.Carnesecchi, K.Langley, F.Exinger, F.Gosse and F.Raul, J. Pharmacol. Exp. Ther., 301, 625(2002), DOI: 10.1124/jpet.301.2.625

[RJC-5180/2019] 